\title{
Climate Change Impact on Rural Livelihoods of Small Landholder: A Case of Rajanpur, Pakistan
}

\author{
Muhammad Ateeq-Ur-Rehman ${ }^{1}$, Badar Naseem Siddiqui ${ }^{2,}$, , Naimatullah Hashmi ${ }^{1}$, Khalid Masud ${ }^{2}$, \\ Muhammad Adeel', Muhammad Rameez Akram Khan², Khawaja Muhammad Dawood ${ }^{2}$, \\ Syed Ali Asghar Shah', Madiha Karim ${ }^{1}$ \\ ${ }^{1}$ Department of Sociology, Pir Mehr Ali Shah-Arid Agriculture University, Rawalpindi, Pakistan \\ ${ }^{2}$ Department of Agricultural Extension, Pir Mehr Ali Shah-Arid Agriculture University, Rawalpindi, Pakistan
}

Email address:

abq678@gmail.com(B. N. Siddiqui)

${ }^{*}$ Corresponding author

\section{To cite this article:}

Muhammad Ateeq-Ur-Rehman, Badar Naseem Siddiqui, Naimatullah Hashmi, Khalid Masud, Muhammad Adeel, Muhammad Rameez Akram Khan, Khawaja Muhammad Dawood, Syed Ali Asghar Shah, Madiha Karim. Climate Change Impact on Rural Livelihoods of Small Landholder: A Case of Rajanpur, Pakistan. International Journal of Applied Agricultural Sciences. Vol. 4, No. 2, 2018, pp. 28-34. doi: $10.11648 /$ j.ijaas.20180402.11

Received: February 12, 2018; Accepted: March 30, 2018; Published: April 10, 2018

\begin{abstract}
Climate change is one of the major challenges for agriculture, food security and rural livelihoods for billions of poor people in the world. Agriculture is most vulnerable to climate change due to its high dependence on climate and weather. Asian agriculture sector is already facing many problems relating to sustainability. The present study was conducted to identify the impact of climate change on the socio-economic status and livelihood of farmers. A sample of 280 farmers' respondents was selected from tehsil Jampur of Rajanpur district. The data were obtained through well designed interview schedule and analyzed statistically. All the respondents reported that climate change had always influences on the income and agricultural yield. Climate change had influenced on income and economics weighted scores (1400). Although there were differences between (before -2930832.1) and (current -2684400.0) annual income. All of the respondents reported that climate change had very high effect on the practicing crop diversification while, more than half $(53.0 \%)$ of the respondents reported that climate change had very high effect on planting different crops. The rank order regarding crop diversification was on high rank due to the high weighted score (1400). All of the respondents reported that climate change had greatly extent on forest burning. The comparisons of different means of different factors like mobility, health, economics, income, environmental destruction, agricultural yields and size of land holding affected by climate change were non-significant. The comparisons of different means of different factors like deforestation, pollution from vehicles, pollution from power generation, pollution from waste, pollution from agri. Activities, shifting cultivation, forest burning and any other factors were non-significant.
\end{abstract}

Keywords: Climate Change, Livelihood, Livestock, Rajanpur, Pakistan

\section{Introduction}

Pakistan economy is mainly agrarian so highly sensitive regarding climate change. As a result of change ability in floods, droughts are experiences due to prolonged monsoon rains. Due to this factor, food security, water necessity and energy necessities in Pakistan are under great threat [1]. The main pillar of Pakistan's economy is agriculture which comprised of (livestock and crops). The agriculture sector contributes $21.8 \%$ to GDP of Pakistan and provides basic needs for $60 \%$ of the population. Agriculture is a major source of employment for poor people and famers as it calls for around $41.7 \%$ of the labor force the $67.5 \%$ of population that is living in rural areas is directly and indirectly linked with agriculture for sustain their livelihood and country's economic [2]. The agrarian livelihoods mainly depend on income from producing agricultural commodities and raising livelihood. Droughts threaten the income with variety of immediate affects e.g. reduce milk production and crop failure which will serve as assets of the future income. 
Generally, livelihood security depends upon sufficient, sustainable access resources and income so that one can meet essential needs for famers. Climate changes not only disturb the livelihoods of people but also reduced the national development of developing countries around the world. Heavy rains fall pattern at the time of mature crop destroy the whole crop and poses the worst impact on livelihoods [3].

Several people believe agriculture is most vulnerable sector to climate change. This is because climate change affects both agriculture and livestock production inputs and participation. The climate change also impacts agriculture indirectly by affecting emergency and distribution of pets and livestock diseases. Aggravating frequency distribution of adverse weather condition that decreasing water supplies and irrigation but also increasing necessity of soil erosion [4]. Bangladesh is one of the most climate change vulnerable country in the world which is highly susceptible to the agricultural damage and livelihood of the small landholders. Small scale farmers in developing countries like Bangladesh are most likely affected due to climate change because they totally depend on the agriculture for the securing of their livelihood [5]. Climate change has a great variability on the agriculture is expected to manifest through changes in water regimes and land specially changes in frequency and intensity of flooding, water shortage, plant diseases, livestock, low and weak crop production that directly causes for decrease the livelihood of rural farmers [6].

It is difficult to adopt the latest technology and innovation by the poor farmers who live in marginalized areas and they are facing the extreme environment and other problems like, harm temperature, natural disaster, rainfalls and droughts. While these framers are trying to save their livelihood under high pressure of climate change that vulnerable for food security. The farmers have no idea about the new technologies and innovation so that they may increase their crop production and secure their livelihood [7]. This includes agriculture, food security water supply, health, displacement, human settlement livelihoods; finance and socio political are related to climate change. These climate change factors help us to understanding the deeper shocks [8]. Climate change is created high level of poverty along with reduced options for facing economic shocks. Poor farmers can cope farming with livelihood by rearing rabbits, chicken, goat and snails to enhance their farming. They can engage themselves in such activities specially in rainy season while most of their agriculture land in flooded [9].

Agriculture demands for good management because it fulfills the needs of basic need of food security but climate has a harsh impact on agriculture. Natural climate and land plays an important role for food production but improper management could pose negative impact on the food security, livelihood and their socio-economic condition [10] In this context, [11] farmers used traditional methods for crop production in Pacific Island countries comprise of substance selling products, fishing, farming, hunting and gathering. But still they use the traditional methods for securing the basic livelihoods. On the other hand, developed countries, forced the underdeveloped countries for growing good crops for modern countries but the farmers used the low quality of food and consuming low products. [12] argued that the economy of many developing countries like Sudan is mainly based on farming and livestock which provide the major employment of that region. Majority of population (70\%) depends on traditional and subsistence agriculture and pastures. It is difficult to make the good earning of farmers in highly risk of climatic changes. These changes of climate change cause for the threat of many farmers in local areas.

It is estimated the temperature average will increases by $20-40^{\circ} \mathrm{C}$ by year 2080 . The rise in temperature poses a great threat to the yield of crops and it will be difficult to control and maintain the increasing population and the world food system [13]. Warming has specifically constrained agriculture and crops yields productivity of dry and low attitude region. This affected food security and nutrition at national levels along with livelihoods of the poor communities through raising lower productivity, reduced employment, food prices, and eco system [14] Food production is badly affected by climate change and the crops which are least able to cope have additional negative impact. It has been noticed that Africa is the most vulnerable region that effected by global climate change because of the nonadopting of the new innovation which resulted low productivity against climate change. Furthermore poverty, dependency on rain for agriculture activities, lack of economic and technical sources, education regarding agriculture and safety nets reduces the agricultural yields [15]. According to [16] during the process of human civilization the people all over the world have developed ways of earning their livelihoods fulfilled and necessity of basic need of food shelter, water and other goods and services.

This indicated that that climate change had affected on livelihood strategies in all over world. In rural areas of developing countries livelihood are more effected because of low agricultural productivity, decreasing natural resources and unawareness of climate which lead to increase poverty. The farmers and landholders that depend on direct natural environment and rain fed agriculture for food security are more open to impact of climate change [17]. [18] reported that the people in Kaghan Valley shifted to rural places like Mansehra to protect them from harsh climate which resulted in disturbance of their livestock, livelihood pattern thus contributing to poverty, low food production and food insecurity.

\section{Materials and Methods}

\subsection{Sampling}

The present study was conducted in Jampur district Rajanpur. Total 280 respondents were selected for the present study. Out of 19 union councils 14 are rural and 5 are urban union councils respectively. All the rural union councils were served as study area. From each union council two villages 
were selected by simple random technique and from each selected village, 10 farmers respondents were selected conveniently.

\subsection{Preparation of Interview Schedule}

To conduct the study, an interview schedule was developed with the help of literature review and consultation with the expert in the field. The interview schedule comprised of open ended and close ended questions. Researcher conducted face to face, interviews which primarily in English but was asked in local language. The interview schedule was validated by the expert and pre-tested on 20 non-respondents sample.

\subsection{Analysis of Data}

Data was analyzed through Statistical Package for Social Science (SPSS). Descriptive as well as inferential statistics were used to discuss the findings and to draw the conclusion.

\section{Results and Discussions}

\subsection{Rating and Ranking of Climate Change Influence on Various Aspects}

Data shows that climate change had always influence on health and environmental destruction as reported by 45.36 and $42.26 \%$ of the respondents. About one-third (31.43\%) and most $(38.93 \%)$ were of the view that climate change had always effected the agricultural yield and economics of the respondents. About one-fourth (22.50 - 25.00\%) reported that climate change sometimes effected mobility, economics, environmental destruction and agriculture yield. Less number of the respondents were of the view that climate change occasionally and rarely had an influence on these aspects (Table 1).

Table 1. Influence of climate change on various attributes $(n=280)$.

\begin{tabular}{|c|c|c|c|c|c|c|c|c|}
\hline \multirow{2}{*}{ Influence of climate change } & Rarely & Occasionally & Never & Sometime & Always & \multirow{2}{*}{ Weighted score } & \multirow{2}{*}{ Mean } & \multirow{2}{*}{ Rank } \\
\hline & Percentage & & & & & & & \\
\hline Mobility & 36.43 & 12.50 & 19.64 & 22.86 & 8.57 & 713 & 2.55 & $6^{\text {th }}$ \\
\hline Health & 0.71 & 2.86 & 22.86 & 28.21 & 45.36 & 1161 & 4.15 & $1^{\text {st }}$ \\
\hline Income & 24.29 & 18.57 & 12.86 & 16.07 & 28.21 & 855 & 3.05 & $5^{\text {th }}$ \\
\hline Destruction & 3.21 & 5.71 & 22.50 & 25.71 & 42.86 & 1118 & 3.99 & $2^{\text {nd }}$ \\
\hline Agricultural yield & 17.50 & 17.14 & 25.00 & 8.93 & 31.43 & 895 & 3.20 & $4^{\text {th }}$ \\
\hline
\end{tabular}

Furthermore, respondents ranked climate change effect on health as $1^{\text {st }}$ with highest weighted score (1161). Climate change effect on economics, destruction of environment, agricultural yield and income were come under never to sometime but environmental destruction and economics shows their inclination towards sometime. Whereas agricultural yield and income tended towards were influences of climate change and ranked $4^{\text {th }}$ and $5^{\text {th }}$ with weighted scores of 895 and 855 respectively. Effect of climate change and mobility stood at last with lowest weighted score (713).

\subsection{Rating and Ranking of Main Constraints in Mitigating Climate Change}

The data reflects that all the respondents were of the view that practicing crop diversification was responsible to mitigate the effect of climate change. Half (50.4\%) and most ( 41.1 to $46.4 \%$ ) of the respondents related soil conservation, different planning dates, movement to different sites and planting different verities as may highly responsible for mitigating climate change and its effect. Further, planting different crops were considered highly responsible constraint in mitigating effect of climate change as reported by slightingly more than half $(53.0 \%)$ respondents. All the respondents pointed out insurance usage as constraint against mitigating climate change effect at low level.

The data in Table 2 depicts that among the various factors that constrains the climate change on practicing crop diversification was ranked at top $\left(1^{\text {st }}\right)$ having highest weighted score (1400) and mean (5.00). Soil conservation, planting different varieties and different planting dates were come in between medium and high categories $(\overline{\mathrm{X}}=4.19$, 4.10, and 4.15) but all declined towards medium categories and ranked $2^{\text {nd }}, 3^{\text {rd }}$, and $4^{\text {th }}$ with weighted score of 1172 , 1148, and 1114 respectively. Moreover, shorten growing periods planting different crops, shading and shelter fell in between medium and high categories $(\overline{\mathrm{X}}=3.20,3.59$, and 3.21). Planting different dates inclined more towards high categories and ranked at $6^{\text {th }}$ place moving towards site placed at bottom with lowest weighted score (280) and come in many low categories.

Table 2. Ranking of various constraints in mitigating the effect of climate change on the livelihood ( $n=280)$.

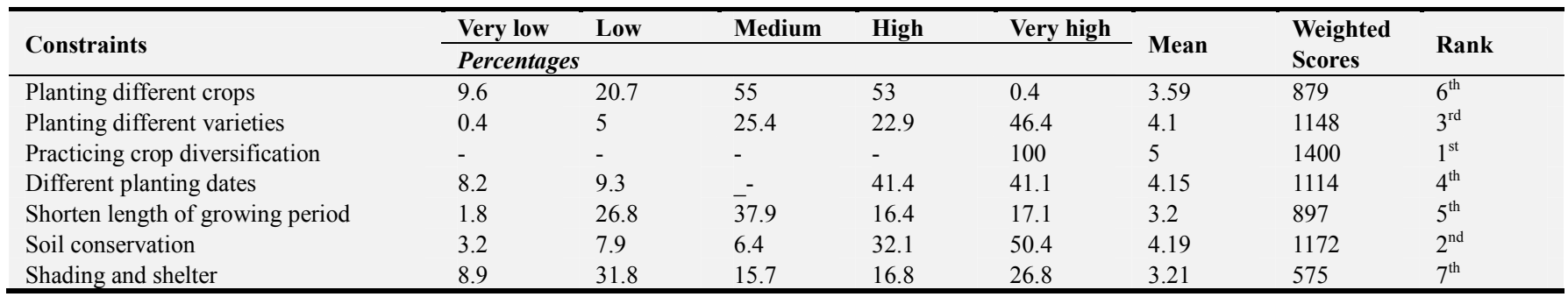




\begin{tabular}{|c|c|c|c|c|c|c|c|c|}
\hline \multirow{2}{*}{ Constraints } & Very low & Low & Medium & High & Very high & \multirow{2}{*}{ Mean } & \multirow{2}{*}{$\begin{array}{l}\text { Weighted } \\
\text { Scores }\end{array}$} & \multirow{2}{*}{ Rank } \\
\hline & \multicolumn{5}{|c|}{ Percentages } & & & \\
\hline Use insurance & 0 & 100 & - & - & - & 2.05 & 575 & $7^{\text {th }}$ \\
\hline Other adaptations & 100 & - & - & - & - & 2 & 560 & $8^{\text {th }}$ \\
\hline Move to different site & 0.4 & $\overline{5}$ & 25.4 & 22.9 & 46.4 & 1 & 280 & $9^{\text {th }}$ \\
\hline
\end{tabular}

\subsection{Climate Change on Crops}

In agriculture water, seed and land are main components. Rain fee areas of Pakistan have good capacity to increase more productivity if good varieties of seeds are available. Agriculture extension services may help the farmer to give knowledge about climate change. Climate change is natural factor but human create pollution that resealed high temperature in atmosphere the result climate change [19]. Data shows that less numbers (17.1 and $7.86 \%)$ of the respondents were show their agree and strongly agree response that climate change had effect on agricultural yield. Less than half (46.4\%) and one-fifth (22.8\%) were show their agree and strongly agree response that climate change has effect as landholders. While all of the respondents were strongly disagree about climate change effect on specific crops and vegetable, but most $(41.43 \%)$ of the respondents were disagree that climate change had caused changing in weather condition.

The data in table depicts that among the effect of climate change on specific crops and vegetable was ranked at top $\left(1^{\text {st }}\right)$ having highest weighted score (1400) and were show disagreement of the respondents $(\overline{\mathrm{X}}=5.00)$. Landholders was ranked at $\left(2^{\text {nd }}\right)$ with weighted score (1148) that falls between disagree and strongly disagree and tended towards disagreement of the respondents $(\overline{\mathrm{X}}=4.10)$. Moreover, effect of climate change on weather and agricultural yield categories $3^{\text {rd }}$ and $4^{\text {th }}$ with weighted scores of 1114 and 803 respectively.

\subsection{Various Causes of Climate Change}

Oceans, plants, trees and rest of it is mounted up in atmosphere the burning of fossil fuel (coal, natural gas and oil) release $\mathrm{CO}_{2}$ in large number in to the air half of this is fascinated by oceans, trees, and plants and remaining $\mathrm{CO}_{2}$ remain in the air [20]. Climate change mean major changes in, rainfall, temperature, winds and snow pattern lasting for a long time or decades. Human and natural factors are the causes of climate change. Human are cutting down forests, developing land for farms, green houses, cities and roads. Changes in earth orbit, sun force the circulation of the atmosphere and ocean. Glaciers are also most sensitive indicator of climate change. Glaciers produce and minimizes due to both unpredictability and external power.

The data in Table 4 reflects that all $(100 \%)$ the respondents were of the view that forest burning was the causes of climate change to great extent. While more than half $(54.3 \%$ to $58.2 \%$ ) of the respondents responded that deforestation and pollution from vehicle were causes of climate change to great extent. Moreover, more than one-third $(31.4 \%$ to $39.6 \%$ ) of the respondents reported that pollution from vehicle, deforestation were the other causes of climate change to some extent. However, more than half $(51.4 \%$ to $52.5 \%$ ) of the respondents argued that pollution from wastage and from power generation were causes of climate change to some extent. However, pollution from agricultural activities was not at all the causes of climate change for $(31.8 \%)$ of the respondents.

Table 3. Rating and ranking of climate change effect on agriculture as perceived by respondents.

\begin{tabular}{|c|c|c|c|c|c|c|c|c|}
\hline \multirow{2}{*}{ Effect } & Strongly agree & Agree & Neutral & Disagree & Strongly Disagree & \multirow{2}{*}{ Weighted score } & \multirow{2}{*}{ Mean } & \multirow{2}{*}{ Rank } \\
\hline & Percentage & & & & & & & \\
\hline Agricultural yield & 7.86 & 17.1 & 67.1 & 3.21 & 4.6 & 803 & 2.87 & $4^{\text {th }}$ \\
\hline Landholder & 0.36 & 5.00 & 25.3 & 22.8 & 46.4 & 1148 & 4.10 & $2^{\text {nd }}$ \\
\hline Specific crops and vegetable & - & - & - & - & 100.0 & 1400 & 5.00 & $1^{\text {st }}$ \\
\hline Change weather & 8.21 & 9.29 & - & 41.43 & 41.0 & 1114 & 3.98 & $3^{\text {rd }}$ \\
\hline
\end{tabular}

Table 4. Percentage distribution of various causes of climate change as perceived by the respondents $(n=280)$.

\begin{tabular}{llll}
\hline \multirow{2}{*}{ Causes } & To great extent & To some extend & Not at all \\
\cline { 2 - 4 } & Percentage & & 39.6 \\
\hline Deforestation & 54.3 & 31.4 & 6.1 \\
Pollution from vehicle & 58.2 & 52.5 & 10.4 \\
Pollution from power generation & 28.2 & 51.4 & 19.3 \\
Pollution from waste & 34.3 & 42.9 & 14.3 \\
Pollution from agriculture activities & 25.3 & 41.1 & 31.8 \\
Shifting cultivation & 32.5 & - & 26.4 \\
Forest burning & 100 & - \\
\hline
\end{tabular}

\subsection{Comparison of Various Causes for Climate Change}

The comparisons of different means of different factors like deforestation, pollution from vehicles, pollution from power generation, pollution from waste, pollution from agri. Activities, shifting cultivation, forest burning and any other factors were non-significant so $\mathrm{H}_{\mathrm{o}}$ is rejected at 0.05 (significance level) Table 5 . 
Table 5. Comparison of various causes responsible for climate change $(n=280)$.

\begin{tabular}{|c|c|c|c|c|c|c|}
\hline \multirow{2}{*}{ Impact } & \multirow{2}{*}{$\begin{array}{l}\text { Male } \\
\text { Mean } \\
\end{array}$} & \multirow[b]{2}{*}{ SD } & \multicolumn{2}{|c|}{ Female } & \multirow{2}{*}{$\mathbf{T}$} & \multirow{2}{*}{ Sig. } \\
\hline & & & Mean & SD & & \\
\hline Deforestation & 1.47 & .568 & 1.56 & .648 & 102 & $.044^{\mathrm{NS}}$ \\
\hline Pollution from vehicles & 1.47 & .651 & 1.63 & .682 & -1.972 & $.376^{\mathrm{NS}}$ \\
\hline Pollution from power generation & 1.91 & .698 & 1.91 & .673 & -.087 & $.517^{\mathrm{NS}}$ \\
\hline Pollution from waste & 1.82 & .638 & 1.78 & .700 & .535 & $.063^{\mathrm{NS}}$ \\
\hline Pollution from agri. activities & 2.01 & .773 & 2.12 & .734 & -1.269 & $.916^{\mathrm{NS}}$ \\
\hline Shifting cultivation & 1.93 & .755 & 1.95 & .780 & -.233 & $.621^{\mathrm{NS}}$ \\
\hline
\end{tabular}

t cannot be computed because the standard deviations of both groups are same

\subsection{Comparison of Income of the Respondent Through Various Agricultural Activities}

Comparison of the current and 2 years back income earned through on-farm and off-farm assets shows in Table 6. The mean of current income generated from crop production was 2.308 million and 2 years back mean income was 2.6844 million rupees. The t-test show non-significant because the value of $\mathrm{t}$ is greater than $\mathrm{p}$ value at $0.05 \%$ level of significance. On the other hand, the mean of current income generated from the livestock was 0.179 million and 2 years back mean income was 0.194 million rupees. The T- test value shows significant because the value of $t$ is smaller than $\mathrm{p}$ value at $0.05 \%$ level of significance. While the mean of current income generated from different other sources was 0.24 million and 2 years back mean income was 0.587 million rupees. The $\mathrm{T}$ - test value shows significant because the value of $\mathrm{t}$ is smaller than $\mathrm{p}$ value at $0.05 \%$ level of significance. On the other side the non- farm income of farmers also disturbed. The mean of current income from business 0.52 million and 2 years back was 0.577 million rupees. The t-test show non-significant because the value of $t$ is greater than $p$ value at $0.05 \%$ level of significance.

Table 6. Comparison of various on farm and off-farm assets of the respondents $(n=280)$.

\begin{tabular}{|c|c|c|c|c|c|c|c|}
\hline \multirow{2}{*}{ Assets } & \multirow{2}{*}{ Commodity } & \multicolumn{2}{|c|}{2 Years back } & \multicolumn{2}{|c|}{ Current } & \multirow{2}{*}{ t-test } & \multirow{2}{*}{ Sig. } \\
\hline & & Mean & SD & Mean & SD & & \\
\hline \multirow{6}{*}{ On-farm } & Crop & 2.9308 & 1.5847 & 2.6844 & 3.0769 & 1.52 & $.129^{\mathrm{ns}}$ \\
\hline & Livestock & 0.1946 & 0.3924 & 0.1304 & 0.1787 & 3.27 & $.001^{*}$ \\
\hline & Machinery & 0.0580 & 0.1294 & 0.0421 & 0.0991 & 6.01 & $.000^{* *}$ \\
\hline & Tube well & 0.0054 & 0.0344 & 0.0034 & 0.0192 & 1.97 & $.049^{* *}$ \\
\hline & Orchard tree & 0.1236 & 0.1794 & 0.0917 & 0.1480 & 6.49 & $.000^{* *}$ \\
\hline & Vegetables & 0.4811 & 0.2999 & 0.4058 & 0.2739 & 9.24 & $.000^{* *}$ \\
\hline \multirow{3}{*}{ Off-farm } & Business & 0.5304 & 0.7320 & 0.4488 & 0.7307 & 2.14 & $.033^{*}$ \\
\hline & Cottage industries & 0.0485 & 0.1283 & 0.0394 & 0.1076 & 2.87 & $.004^{*}$ \\
\hline & Others & 0.5777 & 0.2849 & 0.5208 & 0.3332 & 3.39 & $.001^{*}$ \\
\hline
\end{tabular}

\subsection{Comparison of Different Factors that Causes for Climate Change}

The comparisons of different means of different factors like deforestation, pollution from: vehicles, power generation, waste, agricultural activities, shifting cultivation, forest burning and any other factors were non-significant so $\mathrm{H}_{\mathrm{o}}$ is rejected at 0.05 (significance level) Table 7.

Table 7. Comparison of different factors that causes for climate change $(n=280)$.

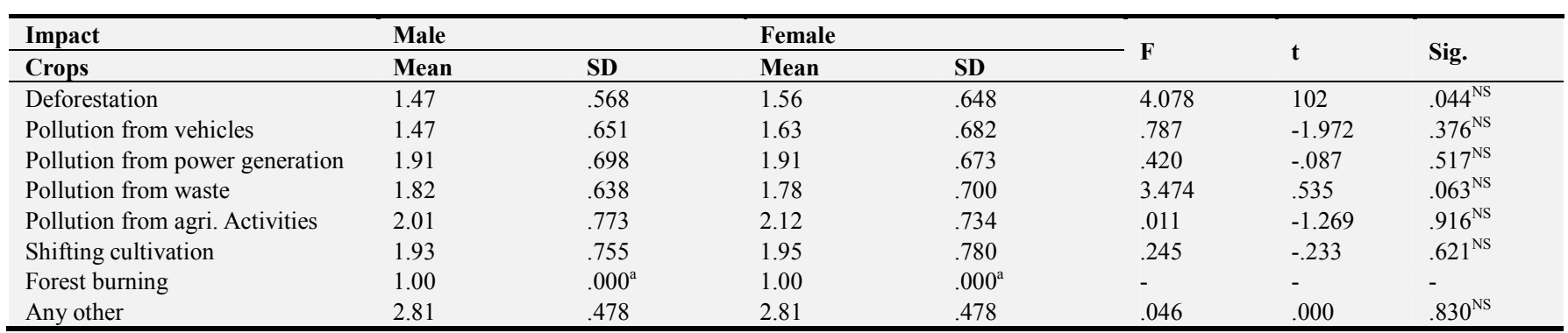

$\mathrm{t}$ cannot be computed because the standard deviations of both groups are 0 .

\section{Conclusion}

This study was conducted to examine to study the effect of climatic change on rural livelihood of farmers. Rural livelihood totally depends on agricultural activities that directly depend on the natural temperature but changes in natural temperature causes for heavy rains, floods and drought that directly affect the agricultural activities and 
agricultural yield. The incomes of small landholders directly affected due to climate change because the due to climate change agricultural yield effected. While Changes in natural temperature directed cause for the unscheduled rains, flood that cause for the damage of mature crops of small landholders. The livelihood also causes for the weak health condition of the small landholder. The agricultural sector (crops and livestock), which is the main source of food and income (livelihood) for majority of local the people in the area damage. So the farmers are unaware from the changes of climate change.

\section{Recommendation}

1. There is need to develop crop varieties that are resistant to climate resistance varieties by the agricultural researchers and this must be introduce to the farmers to enhance agricultural production which plays an important role in achieving food security and livelihood.

2. There is need to protect natural resources and also need to create diverse livelihood opportunities for the people to secure their livelihoods.

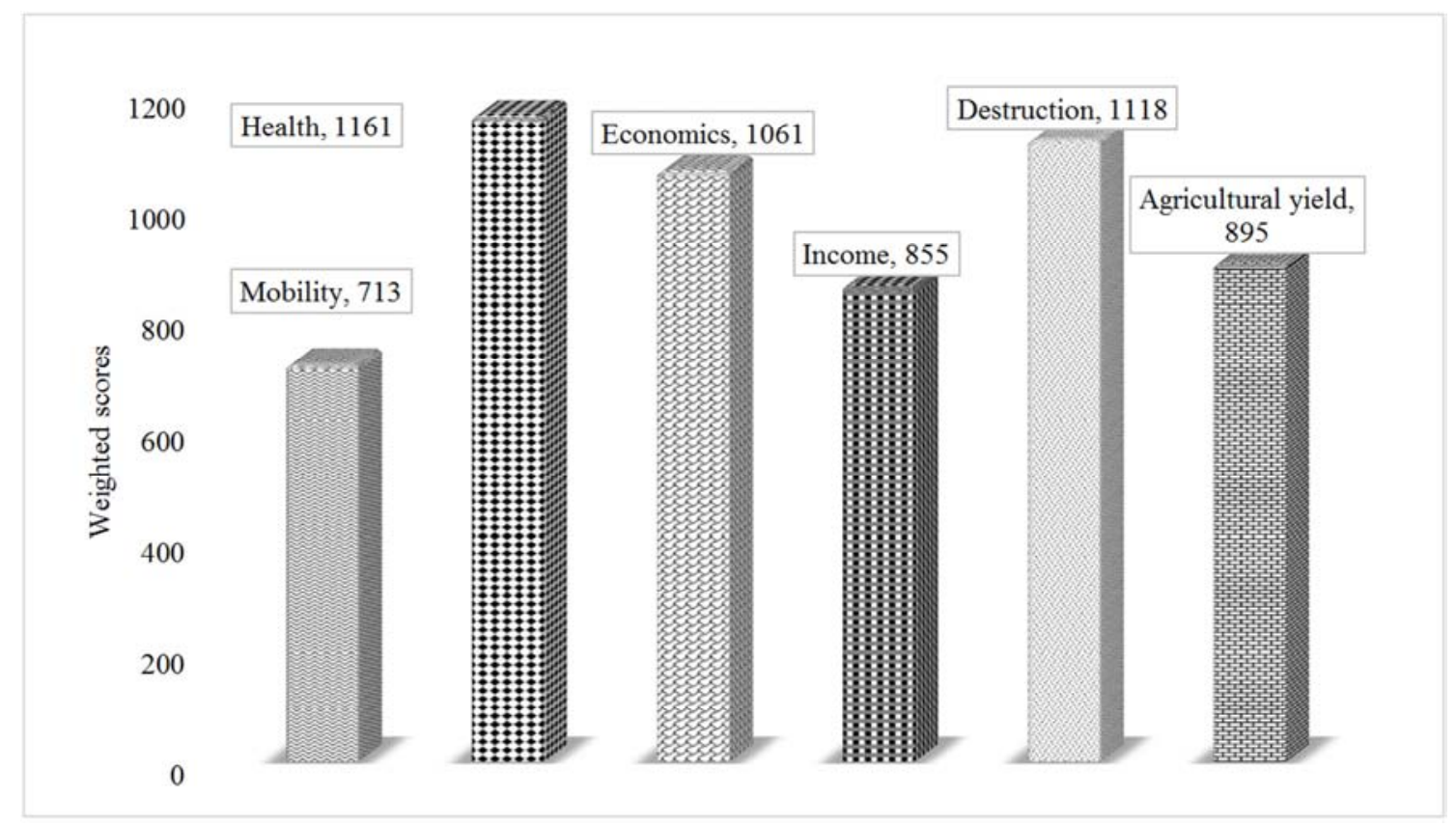

Figure 1. Ranking of climate change influence on various attributes.

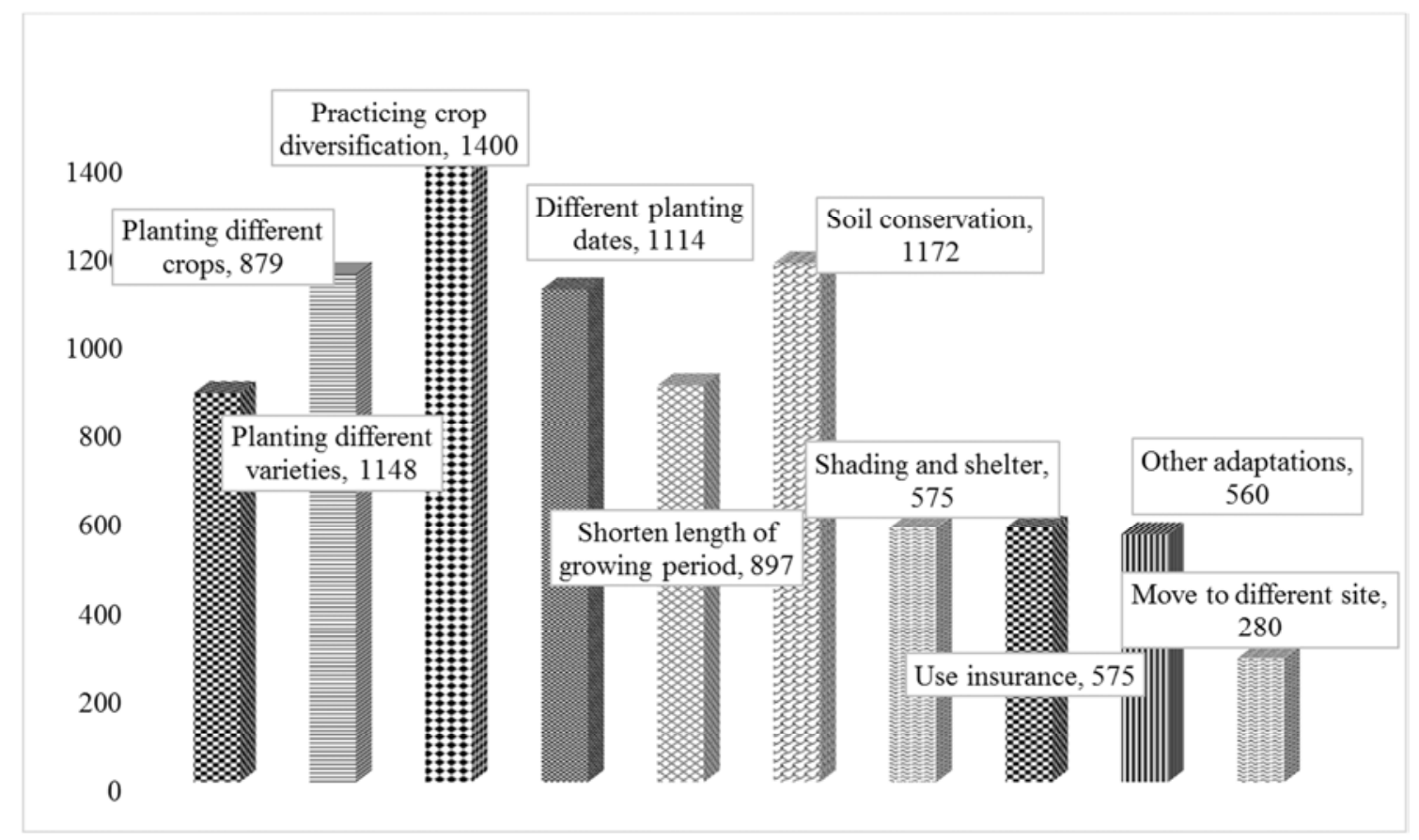

Figure 2. Ranking of constraints in mitigating the effect of climate change on the livelihood. 


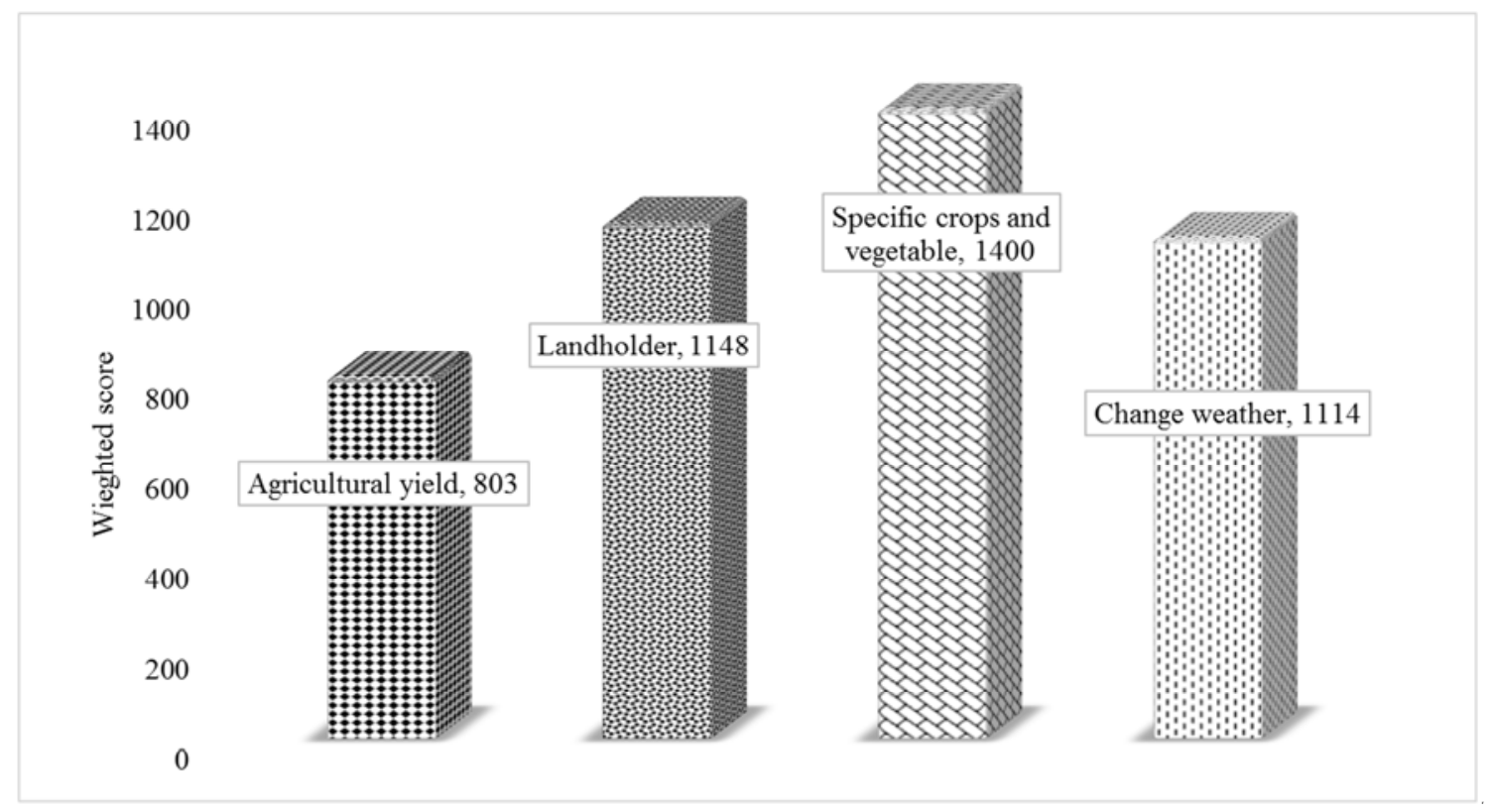

Figure 3. Rating of climate change effect of agriculture as perceived by the respondents.

\section{References}

[1] Ladd, G. and V. Suvannunt, 2010. A model for consumer demand for good characteristics. American J. Agri. Eco., (58): 504-510.

[2] Govt. of Pak. 2011. Annual Plan 2011-12. Planning Commission, Planning and development Division, Islamabad.

[3] Fafchamps, C. 2000. Drought and saving in West Africa: are livestock a buffer stock. J. Dev. Econ. 55 (2):273-305.

[4] IPCC, 2007: Climate Change 2007: The Physical Science Basis. Contribution of Working Group I to the Fourth Assessment Report of the Intergovernmental Panel on Climate Change [Solomon, S., D. Qin, M. Manning, Z. Chen, M. Marquis, K. B. Averyt, M. Tignor and H. L. Miller (eds.)]. Cambridge University Press, Cambridge, United Kingdom and New York, NY, USA, 996 pp.

[5] Karim, M. R., and Ishikawa, M., 2012. Climate change model predicts 33\% rice yield decrease in 2100 in Bangladesh. Agron. Sustain. Dev. 32, 821-830.

[6] Schlenker, W., and Lobell, D., B. 2010. Robust Negative Impacts of Climate Change on African Agriculture. Environ. Res. Lett. 5:014010.

[7] Mirza, M. Q. 2003. Climate change and extreme weather events: Can developing countries adaption. Clim Poli. 3 (3):233-248.

[8] Magrath, J. 2008. Turning Up the Heat: Climate Change and Poverty in Uganda, Kampala,

http://www.oxfam.org.uk/resources/policy/climate_change/ climate change. pdf.

[9] NEST, 2004. (Nigerian Environmental Study Action Team), Nigeria Global GCSI, Change Strategies International, Canada. 2004. Executive Summary of Five Multi-Sector Surveys on Nigeria's Vulnerability and Adaptation to Climate Change.
[10] Gunnell, A. N, G. Agmalian. 2005. Agriculture land available for production in 2030. Roots of the Change Fund Report. San Francisco, USA.

[11] Barnett, J. 2007. Food Security and climate change in the South Pacific, Pacific Ecologist Advisory Panel. J. Pac. Ecol, 32-36.

[12] Abdallah, N. 2009. Climate Change Diary, Sudan, retrieved through http://www. practicalaction.org on 2009/07/21.

[13] Nelson, G. 2010. Climate change: Impact on agriculture and cost of adaptation. International Food Policy Research Institute. Washington DC, USA.

[14] Ensor, J. 2011. Uncertain Futures: Adapting Development to a Changing Climate. Warwickshire: Practical Action Publishing.

[15] Bako, M. 2013. Climate change vulnerability assessment in parts of Northern Nigeria. Nigerian J. Trop. Geogr., 4 (2): $449-470$.

[16] Kulkarmi, J. and N, Leary. 2007. Climate Change and Vulnerability in Developing Country Regions. Draft Final Report of the AIACC Project, A Global Environmental Facility Enabling Activity in the in the Climate Change Focal Area, Project no GFL - 2328-2724-4330, April 2007, UNEP, Nairobi Kenya.

[17] Whande, W. 2007. Arid climate adaptation and cultural innovation in Africa, program for land and agrarian studies, UWC. http://www.wcs-

ahead.org/gltfca_march2007/whande.pdf. Accessed on 18-062016.

[18] Martin, F. J. 2007. The impact of climate change on small and subsistence agric. PNAS (Proceedings of the National Academy of Sciences. 104 (50).

[19] Trenberth, K. and R. Karl. 2003. Modern global climate change. Science. KPK during winter season. Pak. J. of Mete., 7 (13) Pp. No 115-117.

[20] NAS, 2001. Climate change science. An analysis of some key questions. National Academy Press. Rome, Italy. 